\title{
"Materiality Has Always Been in Play": An Interview with N. Katherine Hayles
}

\author{
Lisa Gitelman
}

N. Katherine Hayles, Professor of English and Media Arts at the University of California, writes and teaches on the relations between science, literature, and technology. Her most recent book, How We Became Posthuman: Virtual Bodies in Cybernetics, Literature, and Informatics (Chicago, 1999), won the Rene Wellek Prize for the best book in literary theory for 1998-99. She is currently at work on two books on electronic textuality, Literature for Posthumans and Coding the Signifier: Rethinking Semiosis from the Telegraph to the Computer.

Gitelman: Your book How We Became Posthuman is one that I find myself returning to again and again. I keep discovering new things in it, and it keeps informing the work I do on technologies of representation. Are you still working on the same or on related issues? Could you describe your current project?

Hayles: Right now I am finishing up a book called Writing Machines to be published in September 2002 with MIT Press in their new Mediawork series edited by Peter Lunenfeld. It carries on some of the arguments of Posthuman but in a different vein. I have become very interested in the possibility of media-specific criticism-a mode of critical inquiry attentive to the materiality of the medium in which a literary work is produced.

Lisa Gitelman is the author of Scripts, Grooves, and Writing Machines: Representing Technology in the Edison Era (Stanford, 1999) and co-editor of the forthcoming New Media, 17401915 (MIT, 2003). She is currently Assistant Professor of English and Director of the Program in Media Studies at Catholic University. 
Writing Machines argues that literary criticism has for much too long tended to regard the literary work as an immaterial verbal construct. My claim is that with significant exceptions, print has become transparent for us because it is ubiquitous, the sea in which we swim. Your own work on inscription technologies is one of those exceptions, of course, along with the criticism of theorists such as Johanna Drucker, Jerome McGann, and Matthew Kirschenbaum. The connecting point with Posthuman is an emphasis on embodiment, now understood as the interplay of a work's physicality with its signifying practices.

Now that electronic textuality is bursting on the scene, it seems we have a magnificent opportunity to think again about the specificities of both print and electronic media, which can illuminate one another by contrast. I hope to electrify the neocortex of literary studies into recognizing that the print book is after all an interface with its own presuppositions, assumptions, and configurations of the reader.

In Writing Machines I discuss three texts as case studies in the specificity of media: Talan Memmott's electronic work Lexia to Perplexia, Tom Phillips's artist's book A Humument, and Mark Danielewski's print novel House of Leaves. Each reading attempts to show how the text engages the materiality of its medium, and how this materiality becomes so entwined with the content that the two cannot be adequately understood apart from one another.

I also wanted to devise a form that would invite in people who have not yet thought much about electronic textuality, which I think includes the majority of literary critics. So the theoretical/critical chapters alternate with narrative chapters centered on an autobiographical persona, Kaye, as she makes the journey from a print-oriented perspective to a media perspective. This scheme is consistent with the aim of the series, which is to produce small-format, richly designed books that will appeal to a general reader as well as an academic audience.

The series matches each author with a print designer to ensure high visual quality for each book. My collaborator is Anne Burdick, a wonderful designer who has won major awards for her print designs and who also designed the new interface for the Electronic Book Review. Her design will be very much an integral part of the text, instantiating in visual form the major themes and ideas. In exploring what a print book can be in a digital age, the Mediawork series seeks to integrate the visual and the verbal, an enterprise that is also central to the arguments in Writing Machines.

Gitelman: Does Writing Machines preserve the category of "the literary"? It seems to me that the literary often goes unquestioned and unexamined in ways that the liberal humanist subject does not, although the two are obviously overlapping or mutually acting constructions.

Hayles: Yes, I do put considerable emphasis on the literary. With the proviso, however, that what constitutes this elusive category is continuously changing and mutating.

Part of what I want to demonstrate is that interfaces in both print and electronic 
works are reconfiguring the readerly subject by establishing new relations between voice, (sub)vocalization, articulation, and mark. At least since Marshall McLuhan, we have been inundated with claims that information technologies are transforming subjectivity; I count myself guilty on this score.

But now I think we require microanalyses that show precisely and rigorously how these transformations are being carried out by particular texts, both print and electronic. Not that general claims will be abandoned, of course, but we need a much more detailed understanding of what is involved in these transformations and how they depend on effects specific to the media in which the works are instantiated.

Gitelman: Is this instantiation of a work in a medium what you've called "materiality," or is "the material" another category you think about in newly specific ways? I guess I' $m$ worried that many critics are using the word to mean many different (and different amounts of) things. Is the materiality of a text the literal fact of its existence in one medium or another, or is it some range of forensic properties that help to produce its meaning?

Hayles: Materiality, as I use the term, does not simply mean all the physical, tangible aspects of the construction, delivery, and reading apparatus. Rather, materiality is a selective focus on certain physical aspects of an instantiated text that are foregrounded by a work's construction, operation, and content. These properties cannot be determined in advance of the work by the critic or even the writer. Rather, they emerge from the interplay between the apparatus, the work, the writer, and the reader/user.

Determining what counts as the materiality of a given work is thus both a creative act by the writer and an interpretive act by the user, as well as an engagement of the cognitive properties of an intelligent machine for texts written and implemented on a computer. I don't see this as a cause for anxiety. Materiality has always been in play, even when it was relatively suppressed within literary criticism by considering the work an immaterial verbal construction. In works that foreground their interaction with materiality- "technotexts" is the term I have coined for such works-the material properties are actively constructed by the text and made resonant with significance, becoming semiotically important components of the text's meaning-making processes.

Gitelman: I think I had misunderstood your use of the term and see how rich the notion of materiality as a textual practice can be, in effect, as something that happens rather than something that exists, almost like opening the notion of reader response criticism wide enough to let the varied and variable conditions of the medium in. This seems directly related to the work of what you call the "flickering signifier." Is that right?

Hayles: When I coined the phrase "flickering signifier," I had in mind a different relation between the signifier and signified than that which had been previously 
articulated in critical and literary theory. As I have argued elsewhere, the signifier as conceptualized by Saussure and others was conceived as unitary in its composition and flat in its structure. It had no internal structure, whether seen as oral articulation or written mark, that could properly enter into the discourse of semiotics.

When signifiers appear on the computer screen, however, they are only the top layer of a complex system of interrelated processes. Marks on the screen may manifest themselves as simple inscriptions to a user, but properly understood they are the visible, tangible results of coding instructions executed by the machine in a series of interrelated processes, from a high-level programming language like Java all the way down to assembly language and binary code.

I hoped to convey this processural quality by the gerund "flickering," to distinguish the screenic image from the flat durable mark of print or the blast of air associated with oral speech. The signifier on screen is, as you know, a light image produced by a scanning electron beam. The screen image is deeply layered rather than flat, constantly replenished rather than durable, and highly mutable depending on processes mobilized by the layered code, as for example when a writer uses Flash to create animation or layers that move. These qualities are not merely ornamental but enter profoundly into what the marks signify and, more importantly, how they signify. We need a theory of semiotics that can account for all the qualities connoted by "flickering."

Gitelman: In my work I've been trying to work through what semiotics might mean for history - not the "gee-whiz we're making history" sort of history, but rather the history that historians do, the disciplinary practice of history. Do you have any suggestions on that score? Clearly there are mutual changes emerging between the literary and its subjects, and your work is crucial to explaining how that's happening. But what about mutual changes that may be emerging between history and its subjects? What if, for instance, the Macy Conferences you discuss in Posthuman had all been on-line proceedings instead of stenographically recorded and then printed in proceedings? In short, mustn't cybernetics have emerged the way it did because of ITS (decidedly non-cybernetic) materiality somehow?

Hayles: It remains an ironic fact that our most durable record of information processes and digital writing are print inscriptions. The deeper we advance into digital technologies, the more apparent it becomes that print is a far superior medium for archival purposes.

I think we are still sorting out our relation to the important and intractable problems of digital archiving. I am especially concerned with building and conserving an archive of electronic literature, in a technological environment where any electronic work is likely to be unplayable in $3-5$ years, certainly by a decade. How will we achieve the depth, breadth, and quality of the print archive-a treasure store without which the practice of literature would be unthinkable-for electronic works? This crucial issue is currently being addressed by a number of organizations, including museums, text-encoding initiatives, and in the case of literature, the Electronic Literature Organization. Historians accept the idea that without an archive, 
the discipline would be impossible. The same goes for literature.

Gitelman: Yes, what about the future. I'm sure you've noticed the press that Francis Fukuyama's new book is getting, which uses "posthuman" in its title. Can you reflect on the "legs" your work has and is having? What do you make of where it turns up and how?

Hayles: The first time I heard the word "posthuman," I thought, "This is a viral term for sure!" I knew it would replicate quickly, and I wanted to have some input on how it was interpreted and constructed. As you know, in How We Became Posthuman I argue that there has been a tradition of erasing embodiment in cybernetics, artificial intelligence, and artificial life. How We Became Posthuman shows where some of these erasures occurred, demonstrates their consequences, and argues that embodiment should be written back into the picture.

I wrote the book in part to try to come to terms with my own ambivalences about posthuman developments. In a broad sense, these can be divided between the biological (genetic engineering, etc.) and cybernetic (artificial life, robotics, etc.), although from the beginning there have been strong connections between these two strands, and hybrid entities are becoming increasingly important, such as silicon chips combined with biological substrates. Posthuman is located within a much broader landscape that includes scientists, engineers, artificial life researchers, and cognitive scientists, as well as cultural and literary critics. There are many stakeholders, of which I count myself one, but since I deal mostly with the cybernetic strand, my work is relatively more distant from the biological strand, about which many others have written more directly. I am in the process of reading Fukuyama's book now, so I cannot speak about it with authority. Nevertheless, it is clear that he is more concerned with the biological strand than I was in Posthuman. I think it's fair to say his view is probably more dystopian than mine, but I share many of his concerns and also worry about the cultural implications of recent developments in cloning and other areas of biomedicine. Eugene Thacker has recently written about some of the biomedical developments as "biomedia," a wonderful term that stresses the confluence of information theory with molecular biology. Studies like his, located at the crossroads of information theory, cybernetics, biology, and media, indicate how entangled these fields have become and consequently how far-reaching their confluence is for many sectors of society.

As for the influence that Posthuman has had, it seems to be part of discussions in Europe and especially in Scandinavia as well as in the U.S. I wrote the book to bring certain issues into current conversations about the posthuman, and to this extent, I think it has succeeded. I am less concerned with whether others agree or disagree with me than I am with wanting the issues to be examined, discussed, and debated.

Gitelman: Where do you see your work going from here?

Hayles: The implications of cybernetics continue to concern me, especially the 
interactions of humans with intelligent machines. Another current project is a book called Coding the Signifier: Rethinking Semiosis from the Telegraph to the Computer, under contract to the University of Chicago Press. It argues that coding technologies, like the telegraph and the computer, have distinctive characteristics that are unlike print and that should be theorized in their own right. Coding the Signifier I see as a theoretical companion to Writing Machines, extending the argument that literary criticism and theory are shot through with assumptions specific to print, though largely unrecognized as such. I evaluate current theories of semiotics and argue that they do not take materiality sufficiently into account.

What would it mean to have a theoretical discourse that can talk about materiality and meaning together? That connects the embodiment of texts to the embodiment of readers/users who respond kinesthetically and proprioceptively as well as intellectually? Literature, I argue, was never only words, never only disembodied verbal constructs. Texts have bodies, readers and users have bodies, and meaning emerges from material engagements with the rich resources of a physically vibrant world as it is crafted through artistic practices and instantiated in artifactual objects and processes. To settle for anything less than a fully embodied and material practice of literary theory and criticism is to risk impoverishing our understanding of the meaning-making practices through which we engage the world.

There has never been a better time than now, when the long hegemony of print is giving way to the dynamic interactions of the contemporary media ecology, to rethink the assumptions of both print and electronic literature. This does not mean, in my view, that print books are about to become obsolete. Print technology is far too robust, durable, and flexible for that. Far from going the way of the dinosaur, books are going the way of the human, changing as we change, mutating as we continue to modify our ideas about who we are and what makes us tick. However posthuman we style ourselves, we are going to be writing and reading books for a long time to come. 